\title{
LA TRASLACIÓN DE PODERES DEL ESTADO EN 1892 Vista por el licenciado Vicente Pineda
}

\author{
Víctor Manuel Esponda Jimeno
}

\section{El documento}

$\mathrm{P}$ or tratarse de un folleto, haberse escrito en circunstancias difíciles e impreso en un lugar indeterminado — quizás Comitán o Zapaluta—, la difusión de esta obra fue restringida, censurada y clandestina. Los ejemplares que se conocen son escasos y no del todo accesibles. Se ignora el número de tiraje de la obra y, por obvias razones, es evidente que una parte fue confiscada, decomisada y destruida. Es por esos motivos que ese opúsculo puede catalogarse como "impreso raro" y pieza de colección. Independientemente de ello, la obra de Pineda es un testimonio histórico que refleja y manifiesta el sentir de un "coleto" decimonónico, apasionado y amante de su pueblo, que de alguna manera puede considerársele el vocero más representativo de la sociedad sancristobalense de su tiempo. Los argumentos, razones y motivos que expone son vertidos con coraje, orgullo, pasión y apología. Fue Pineda un romántico de su ciudad, la enalteció, justificó y promovió con el amor que profesa una madre en defensa y protección de su hijo.

Víctor Manuel Esponda Jimeno, doctorante en Antropología por la UAM-I y estudiante del doctorado en Antropología en el Instituto de Investigaciones Antropológicas de la UNAM, investigador del Centro de Estudios Superiores de México y Centroamérica de la UNICACH, cuerpo académico: Patrimonio sociocultural, especialidad: etnología. Correo electrónico: espondaj@starmedia.com.
Los seis capítulos que componen el manifiesto son un compendio general de la historia sancristobalense y un referente político del desenvolvimiento de Chiapas. Pineda, hombre de letras, abogado, filólogo, historiador, funcionario público... tenía una clara motivación y, ¿por qué no decirlo?, tenía una justificación para defender los intereses de su ciudad natal; por un lado, los preceptos jurídicos que aducía en pro del legítimo derecho que asistía a San Cristóbal como capital original del estado y, por otro, el dilatado background que le precedía, soportado en más de tres centurias de ser ciudad rectora, de facto y de jure, estatus que sin objeción alguna había conservado con beneplácito y aceptación por parte de los poblados de su jurisdicción y comprensión. Pineda, dolido y ofendido, evidencia y critica la medida arbitraria e ilegal que Emilio Rabasa tomó al trasladar — haciendo suya la causa ajena y asumiendo una enorme responsabilidad motu proprio - los poderes políticos a Tuxtla, sin consulta popular y sin razones justificadas.

En el tiempo en que Rabasa determinó trasladar los poderes nunca manifestó ni esclareció públicamente el móvil real que le guió a elegir tan controvertida decisión, no obstante que sabía que le acarrearía antipatías, rencores y odios. En apariencia, el traslado de poderes fue una medida personal que Rabasa puso 
en práctica para favorecer a los comerciantes e incipientes políticos " "liberales" de las tierras bajas; esto en parte es cierto, pero no el motivo central. Véase por qué. Rabasa, descendiente de hombres de negocios y comerciantes, formado intelectualmente y como abogado en un escenario geográfico en el que se habían gestado los movimientos políticos más trascendentes del país y del cual emergieron los líderes y caudillos, Benito Juárez y Porfirio Díaz, que transformaron de fondo las estructuras políticas de la nación y, como corolario, haberse el novel abogado relacionado con las altas esferas de la política nacional, con sus tendencias y proyectos contó con el apoyo pleno del presidente Díaz para poner en marcha un experimento político y económico que permitiría controlar los destinos de una región estratégica, no ha mucho anexada a México, que por su situación de frontera precisaba de rigurosa integración y dominio verticales.

Entre San Cristóbal y Tuxtla mediaban dos obstáculos, uno ideológico de carácter político-religioso y otro económico-geográfico que dilataba el comercio y la comunicación con la capital de la República, y por estar más próxima la primera a la capital del vecino país del cual se había segregado, se tenían algunas reservas de carácter diplomático pues los centroamericanos en varias ocasiones habían tenido pretensiones sobre el territorio chiapaneco, ${ }^{2}$ como lo evidencian los sucesos ocurridos en 1881 y 1885. Con el primer suceso, se pretendió someter al arbitraje internacional los destinos de Chiapas y Soconusco; con el segundo, se convocó a los chiapanecos para sumarse al proyecto de unificación de las Repúblicas Centroamericanas. Desde luego que esto pudo ser una razón poderosa para que Díaz respaldara la decisión de Rabasa, mas hay que agregar otra agravante que debió de coadyuvar: San Cristóbal se reputaba como residencia de "conservadores", muy leales y apegados al Clero, que se oponían y resistían a la tendencia política que orientaba a la nación, política que había abierto sus espacios y riquezas a la inversión extranjera, la cual ya había penetrado en varias regiones del país construyendo carreteras y ampliando vías ferroviarias, implantando empresas agrícolas de productos comerciales — caucho, henequén y café- - y creando compañías deslindadoras de colonización que tenían como cometido específico la explotación forestal y la prospección de yacimientos minerales para su beneficio.

El traslado de poderes a Tuxtla no fue un simple capricho ni un hecho aislado que hubiera decidido Rabasa; fue una medida planeada, consentida y negociada con mucha anticipación, tanto por intereses regionales como nacionales, ya que tal determinación no podía motivarse por propia iniciativa conociendo las consecuencias y efectos que ésta ocasionaría si no contaba con el respaldo y aval de una orden superior venida desde la capital de la República. Contó, asimismo, esta determinación política con la anuencia, simpatía y respaldo de varios "coletos", ya políticos como civiles. Rabasa no tenía motivos para perjudicar a San Cristóbal; sus ancestros fueron originarios de esta ciudad y varios de sus parientes residían allí. La política se antepuso a las lealtades y a los sentimientos.

Una simple referencia genealógica permite conocer que el notable novelista y jurista no tenía animadversión a San Cristóbal, sino quizás resentimientos y diferencias con algunos de los recalcitrantes políticos de la vieja guardia que se opusieron a sus ideas "modernistas y desarrollistas". José Emilio Rabasa Estevanell provenía de dos familias catalanas, los Rabasa y los Estevanell; estos últimos asentados en Chiapas mucho antes que los primeros, y que desde inicios del xIx habían fincado reales en San Cristóbal y emparentado con los Farrera, también de origen hispano pero radicados en dicha ciudad desde mediados del siglo XVIII. Del matrimonio Estevanell-Farrera, que tuvo lugar el 17 de julio de 1812, hubo dos hermanas, a saber, María Manuela Rita, que nació el 22 de mayo de 1813, y María Teresa de San Juan, el 24 de enero de 1817; con ambas casó don José 
Antonio Rabasa Soler; en primeras nupcias con la segunda y por viudez con la primera, madre que fue de Emilio.

Por el lado de los Farrera se contaba un amplio historial político y económico, sus alianzas con diferentes familias oligárquicas chiapanecas los mantuvieron en una situación privilegiada. Los Pineda, mestizos emprendedores e ilustrados, también se vincularon con los Farrera; la esposa del célebre licenciado Emeterio Pineda, doña Manuela Espinosa Zebadúa, fue una de las esposas del abuelo de Rabasa. Tiburcio José Farrera Hidalgo casó en primeras nupcias con doña María Josefa Mercado, ambos padres de doña María Antonia Farrera Mercado, ésta casada con don José Estevanell Aloña y, por consiguiente, abuelos de Emilio Rabasa, de modo que Vicente Pineda era tío político de don Emilio en razón de que los hermanos uterinos del primero eran Farrera Espinosa y él Pineda Espinosa. Asimismo, debe agregarse que el hermano mayor de don Emilio, Ramón Amado, nació en San Cristóbal en 1849 y a esta ciudad estuvo muy allegado, él casó con doña Constancia Esponda, una dama de las antiguas familias aristócratas. Los vínculos de alianza, filiación y consanguinidad pueden extenderse más, pero baste esta simple relación para observar que a Casahonda (1963:13) le asistió la razón al señalar que Rabasa, por disciplina institucional, lealtad política y, desde luego, para defender sus intereses y prolongar su poder caciquil, dividió a la gran familia chiapaneca.

La información relativa al trascendental suceso que tuvo lugar en 1892 es de lo más variada y polémica; los documentos oficiales de la época lo registran como una necesidad imperiosa y urgente; la prensa difunde el hecho bajo el enfoque y tendencias de quienes escriben; hay adulación, crítica e indiferencia. La medida tomada fue sin duda una decisión difícil pues lesionó intereses y privó de su derecho de ser capital a una ciudad que desde su fundación se reputó como la más importante del estado. Es evidente que el traslado de poderes fue una medida política bien pensada y no un capricho del licenciado Rabasa como popularmente se entiende. Desde luego que haberle quitado el rango de capital a San Cristóbal le ocasionó menoscabos, atraso e inercia, pero es sano advertir que - contrario a lo que dice Pineda - en sus 364 años de ciudad rectora, comparándola con otras ciudades de la República, no era mucho lo que había logrado en materia de administración pública, desarrollo económico y social; su raquítico presupuesto, sus precarias rentas, su aislamiento y sus difíciles vías de comunicación la mantuvieron en un in pase y letargo.

Los políticos de Los Altos pasaban sin pena ni gloria, en tanto que en las tierras bajas los empresarios agrícolas y comerciantes ampliaban sus mercados y sus relaciones con el resto del país en razón de su ventajosa situación geográfica y su solvencia en numerario que les permitió establecer una red política que aglutinaba a las principales fuerzas que movían los destinos del país. Rabasa, al igual que Díaz, instauró en Chiapas una dictadura sui generis que manejó desde la capital de la República a su arbitrio durante casi 15 años, y como bien opina Carlos Monsivais (Ruiz, 2000), respecto a su efímero mandato: "su único proyecto, débilmente ejecutado, es el educativo...". Pero para los pocos tuxtlecos acomodados de aquella época, que se vieron beneficiados en sus negocios y empresas, es el héroe, el benefactor y el mejor gobernante que Chiapas ha tenido; evidentemente así debe ser considerado, pues en 1892 de la noche a la mañana "el poblado de prosa municipal y de mestizos liberales, por un golpe del destino y por decisión de un hombre, es habilitada capital del apartado estado de Chiapas" (Casahonda, 1963: 15).

No hay duda de que este suceso despertó pasiones y opiniones encontradas. El traslado de poderes es un hecho consumado y sin la menor duda, viendo las cosas en retrospectiva, una decisión saludable y ventajosa para San Cristóbal. ¿Cómo sería y estaría en la actualidad la vetusta y colonial Ciudad Real de haber seguido como 
capital? Reacciones e intentos hubo para restablecerle su derecho y rango, mas circunstancias del sabio destino se opusieron a ello. La efervescencia política que durante la primera década del xx se presentó respecto a dicho asunto (De Paz, 2004), es sobremanera sugerente, en particular a raíz de la propuesta que hiciera el licenciado Jesús Martínez Rojas en su carácter de diputado del Congreso de la Unión por el primer distrito electoral de Chiapas, así como las enérgicas protestas de los ciudadanos Timoteo Flores Ruiz, Antonio Rivera Gordillo y Manuel Pineda (Esponda, 2000: 25-68), este último hermano menor del autor del referido manifiesto, el cual retoma y replantea los argumentos esgrimidos por Vicente para hacer público que el traslado de poderes fue una acción ilegal que pasó por alto la voluntad del pueblo chiapaneco.

En resumen, Tuxtla y San Cristóbal, ciudades hermanas y rectoras, se vieron beneficiadas con la medida "ilegal" de Rabasa; hoy Tuxtla es una gran ciudad, San Cristóbal siempre lo fue.

\section{El autor}

Fue el quinto de los siete hijos del matrimonio formado por don Emeterio Celidonio Pineda San Juan y doña Manuela Espinosa Zebadúa. Nació Vicente el 21 de enero de 1835 en la ciudad de San Cristóbal, y fue bautizado al día siguiente en la parroquia del Sagrario de la Iglesia Catedral por el cura vicario interino, don José Irineo Vila, siendo su padrino don José Farrera.

Poca es la información que se dispone acerca de la vida de este introvertido filólogo, lingüista, abogado e historiador. Se tiene noticia de que todos sus estudios los realizó en su ciudad natal; ingresó en 1851 en la Universidad Literaria del Estado, donde estudió derecho civil, carrera que concluyó con excelentes calificaciones en 1855.

Su padre, abogado notable y político reconocido, poseía algunas propiedades en la región nororiental del estado, cercanas a Oxchuc, Chanal y Huixtán. Al morir éste en 1850, el joven Pineda heredó dos, Guadalupe y La Naranja — productoras de caña de azúcar, cerdos y maíz-. El frecuente contacto con los indígenas que en sus propiedades trabajaban le permitió aprender con soltura la lengua tzeltal, y como fuera gran aficionado a la filosofía del lenguaje se dio a la tarea de estudiarla en sus aspectos gramaticales y lexicográficos, empresa que le tomó varios años. Merced a sus esfuerzos se dio a conocer la primera gramática de esta lengua, única y original, aventajada y futurista. Andando el tiempo se propuso elaborar y publicar el diccionario de dicha lengua porque, aunque tenía conocimiento de que los padres dominicos de la época colonial habían elaborado algunos vocabularios para apoyar el ejercicio de su profesión, no se conocía impreso ninguno. Así, con gran esfuerzo y esmero formó su original diccionario que, junto con el que compiló fray Domingo de Ara en el siglo XVI, ${ }^{3}$ es la obra más completa y temprana de la lingüística tzeltal.

Dada su privilegiada situación económica, hacía concienzudamente lo que a él le gustaba, y en virtud de que heredó fortuna empleaba gran parte de su tiempo en sus aficiones, siendo una de ellas la reflexión y el análisis de la problemática que aquejaba a su sociedad, además, como era poseedor de una buena biblioteca —que también heredó- leía con avidez libros de historia, filosofía y derecho.

Profesionalmente se desempeñó en algunos puestos públicos - honoríficos - teniendo como objetivo la procuración del bienestar de su pueblo, empeñándose para que sus ocupaciones estuvieran encaminadas a resultados pragmáticos.

Además de atender sus negocios, Pineda gustaba ante todo de leer y escribir, desafortunadamente varios de sus escritos no se han conservado; se sabe que fue redactor y columnista de algunos periódicos de su tiempo, entre ellos La Brújula, El Mosquito y El Eco Liberal, que a mediados de la centuria antepasada dirigió 
su sobrino Flavio Antonio Paniagua, nieto de Ana Joaquina Mayorga Pineda, prima de Emeterio Pineda. Don Vicente fue director de La Bríjula en 1872.

En la elección de diputados al Congreso del estado, que se verificó el 11 de julio de 1869, fue electo diputado suplente por el Departamento de San Cristóbal con 52 votos. Por alguna razón no aceptó de inmediato ese nombramiento, pero al siguiente año tomó posesión del mismo, desempeñó una brillante labor como congresista; entre varias acciones se distingue su "iniciativa de decreto" que presentó en diciembre de 1870 respecto a las atribuciones indebidas que asumían las Juntas de Instrucción Pública, las que habían elaborado propuestas que resultarían gravosas para el pueblo además de anticonstitucionales, pues las iniciativas de dichas juntas "van en contra de lo que nuestra constitución previene en su artículo 33". En tal virtud propuso que:

Para evitar pues, las complicaciones consiguientes a este proceder, y que las Juntas no se excedan en lo sucesivo, de los límites á que deben circunscribirse, someto a vuestra aprobación el siguiente proyecto de decreto, para que con dispensa de trámite, os sirváis aprobarlo, por ser de urgente necesidad y obvia resolución:

Art. 1. ${ }^{\circ}$ Las Juntas de instrucción pública no tienen derecho de hacer iniciativas al Congreso, por ser esto anticonstitucional.

Art. 2. ${ }^{\circ}$ En el inter los fondos públicos no pueden sufragar los gastos

indispensables para establecer un liceo de enseñanza secundaria en cada

Departamento; las Juntas se circunscribirán únicamente á vigilar las

escuelas de enseñanza primaria, en particular las establecidas en los

pueblos de indígenas.

Art. 3. ${ }^{\circ}$ La Universidad Literaria del Estado no está sujeta a la instrucción ni

vigilancia de las referidas Juntas.
Otras propuestas e iniciativas presentó Pineda como congresista y abogado, pero la mayoría se guardan en archivos y minutas y sólo unas pocas vieron la luz pública en periódicos y folletos.

Un suceso histórico del que fue testigo fue la llamada "guerra de castas" o sublevación chamula. Él y Flavio Antonio Paniagua durante 1869 dieron cuenta oportuna en los medios impresos de su tiempo de estos trágicos acontecimientos. Dicha guerra o rebelión era considerada por estos personajes como un problema verdaderamente grave no sólo para la ciudadanía chiapaneca sino para la civilización misma, y en tal sentido reflexionaron sobre sus causas y consecuencias. Transcurridos algunos años, tanto Pineda como Paniagua retomaron el tema; el primero con una perspectiva histórica y el segundo en la literatura. ${ }^{4} \mathrm{En}$ su "clásico" libro, publicado en 1888 bajo el título Historia de las sublevaciones indígenas habidas en el estado de Chiapas - editado conjuntamente con su Gramática y Diccionario de la lengua tzeltal - se descubre a un hombre profundamente preocupado por la condición precaria en que ha vivido el indígena durante años. Atento a esta problemática propuso varias alternativas para "civilizar" (integrar) al indígena; una de ellas era educarlo en su idioma y esta tarea correspondería a la

sociedad civilizada, porque ella es la que trata de que sus costumbres sean aceptadas por aquella [la sociedad indígena]; el gobierno para darse á entender y ser entendido en todo lo que concierne al régimen político y administrativo de los pueblos de su mando, pues causa verdadero escrúpulo imponer penas á algunos indígenas por acciones ú omisiones mandadas o prohibidas, leyes que nadie se ha tomado el trabajo de explicárselas, ni de dárselas á conocer (1888: 7).

Otra opción era que el gobierno del estado instruyera "a los jueces de primera instancia, que a todos los huérfanos de los pueblos indígenas se les dé por tutor 
persona civilizada, capaz de que pueda darles conveniente educación, dedicándolos á aquel oficio para el cual muestren más disposición" (1888:8).

Y por último proponía:

\begin{abstract}
La fusión de razas podría también dar buen resultado, en razón de que los lazos morales y materiales adunarían á los habitantes del Estado, de tal manera, que á la vuelta de algunos años ya no sería fácil distinguir los diversos orígenes. Para poner en práctica este medio, sólo se necesita que nuestro Honorable Congreso acuerde un premio para los hombres y mujeres del pueblo civilizado que contraigan matrimonio con aborígenes... Así esos matrimonios se multiplicarían en beneficio de la sociedad en general, destruyendo con el tiempo la odiosa distinción de razas (Pineda, 1888: 8-9, énfasis mío).
\end{abstract}

Este fue, básicamente, el proyecto indigenista de Pineda. Cabe anotar que respecto a la última propuesta le asistía la razón. La experiencia pasada lo demostraba con buenos ejemplos; en Chiapas durante los siglos XVII-XVIII el proceso de mestizaje se acrecentó y ello lo demuestra la variedad de "castas" que se registran en los censos y libros parroquiales - de bautismos y matrimonios-. No obstante, el mestizaje más frecuente se dio entre las poblaciones de las tierras bajas, donde los negros, mulatos e indios se venían amancebando regularmente. En Los Altos fue diferente y, aunque hubo mestizaje entre criollos e indias y mestizas con criollos, persistió la segregación racial, dando lugar con el tiempo a que a estas cruzas sucesivas se les nombrara "ladinas", para diferenciarlas de los indios, negros, mulatos, etcétera. La propuesta de Pineda tiene una razón clara; su bisabuela, doña Petrona Díaz, indígena, casó con don Vicencio Pineda, éste ladino: sus hijos fueron mestizos. Asimismo, el matrimonio Pineda-San Juan se registra como casamiento de mestizos. Don Emeterio, hijo de dicha unión, contrajo nupcias con doña Manuela Espinosa Zebadúa, ladina, hija de don José Antonio Espinosa, criollo, y viuda de don Tiburcio José Farrera. He aquí un claro ejemplo de lo que él sugería.

Su propuesta de institucionalizar y animar el matrimonio entre indígenas y no indígenas - considerando su tiempo — era aventajada y revolucionaria, sin embargo, resultó quimérica.

Durante los últimos años de su vida padeció agudas dolencias, pero su entusiasmo por el estudio continuó. Nos dice que cuando iba a mandar imprimir su Diccionario enfermó por diez meses consecutivos y aún así, para que su obra no quedara trunca "tuvo la necesidad de formar los borradores para la imprenta, en aquellos intervalos de tiempo en que las dolencias daban algún descanso". El ánimo e interés que tenía por sus estudios históricos y lingüísticos fue tal que no escatimó recursos ni esfuerzos para darlos a conocer, incluso nos informa que en 1878 no había en Chiapas imprenta activa y por ello se vio precisado a comprar una para que se publicaran sus trabajos. Con tan mala salud, Pineda se dio tiempo para escribir sus estudios, el documento que aquí se reproduce — tal y como él lo escribió- fue su última obra, en el que se aprecia que a pesar de sus aflicciones y achaques, el entusiasmo, pasión y entrega por San Cristóbal fueron aún más intensos; por ello se constituye en el opositor más tenaz y conspicuo del traslado de poderes de su capital efectiva.

Retirado de la vida pública y enfermo de gravedad murió el 12 de abril de $1895 ;^{5}$ dejó en su haber una obra de historia y lingüística original que ha servido a estudiosos y al común del pueblo para conocer aspectos sustanciales del terruño. Su fama como benefactor era bien conocida y por ello, como antes se dijo, sus no pocos bienes dispuso que se destinaran para el establecimiento de una escuela para señoritas, deseo que cumplió fielmente el excelentísimo señor doctor don Francisco Orozco y Jiménez en 1906, 
fundando un colegio con personal traído de Francia que puso en manos de las religiosas de La Providencia para su administración y cuidado, tarea que desempeñaron diligentemente ilustrando a muchas niñas de diferentes lugares del estado (Flores Ruiz, 1985: 103).

\section{Obras de Pineda}

1870 "Iniciativa”, La Brújula, tomo I, núm. 86, San Cristóbal Las Casas, p. 2.

1887 Gramática de la lengua treltal que habla la generalidad de los pueblos que quedan al orientey noreste del Estado de Chiapas. Tipografía del Gobierno en Palacio, San Cristóbal Las Casas (reimpresa en 1888).

1888 Historia de las sublevaciones indigenas habidas en el estado de Chiapas; Gramática de la lengua treltal, y Diccionario de la misma, Tipografía del Gobierno dirigida por J. J. Jiménez, San Cristóbal Las Casas (reimpresa en 1986). [ElDr. Fernando Correa Suárez mandó imprimir de su propio peculio un facsímil del apartado referido a las sublevaciones, sin indicar lugar de impresión ni fecha.]

1892 Chiapas. Traslado de los poderes públicos del Estado de San Cristóbal Las Casas a la Ciudad de Tuxtla Gutiérrez, Imprenta de los Chiapanecos Libres de la Frontera, a cargo de Celso Costa, sin lugar de impresión.

1963 "Sublevación de la provincia de Chiapas en el año de 1524", Rebeliones indígenas en Nueva España, pp. 4-61, Vicente Casarrubias (compilador), Instituto de Capacitación del Magisterio, Secretaría de Educación Pública, México (colección Técnica y Ciencia: 18). [Extracto de 1888, que reproduce la "Primera sublevación", la de los chiapanecas.]

1986 Sublevaciones indigenas de Chiapas. Gramática y diccionario tzel-tal, Instituto Nacional Indigenista, México.
Traslado de los poderes públicos del Estado de la Capital San Cristóbal Las Casas a la Ciudad de Tuxtla Gutiérrez. $1892^{6}$

\section{CAPÍTULO I}

¡No es posible guardar más silencio! Las emociones del alma estallan, el corazón se enardece, la sangre hierve, y por fin los labios prorrumpen... Testigos somos de lo que pasa en las funestas y desconsoladoras circunstancias del día, y debido es que rasguemos el empolvado y caliginoso velo del tiempo, para que, a semejanza de nuestros mayores, protestemos una y mil veces contra todo acto de injusticias que se ejecute con el innoble fin de degradar a la Ciudad de San Cristóbal Las Casas, reconocida desde su fundación por capital del estado de Chiapas.

Verdad es que tras de remotas y lejanas épocas ocúltanse grandes y notables acontecimientos sacudidos en vida de valientes generaciones y es un escenario menos ruidoso y trágico que el actual; pero nunca como los que ahora ocurren tan llenos de sensación y novedad, tan ruidosos y aciagos, como no se vieron ni durante el gobierno Colonial, ni después de nuestra primera emancipación política; a pesar de que las dictaduras siempre entronizan a despecho del descontento popular y con agravio de nuestras libérrimas instituciones.

Para que Chiapas recordara siempre la triste suerte que le estaba deparada, en el periodo gubernamental que atravesamos, preciso fuera que constaran en nuestros anales, cada uno de los injustos y extraordinarios hechos de actualidad, que sin excepción de clases ni de partidos políticos. Llaman la atención del estado, de todo México y que muy pronto reclamarán la del mundo entero, pero ya que esto no es posible, al menos por hoy, consignamos siquiera la improcedencia de la última traslación de poderes de esta Ciudad a la de Tuxtla, y esperamos con tranquila conciencia el irrevocable fallo de la posteridad.

Las sombras veneradas de nuestros mayores, de aquellos aguerridos moradores de San Cristóbal Las 
Casas. Que jamás pudo nulificar por completo la opresión; que no se doblegaron alagados por viles intereses; que nunca sucumbieron ante la tiranía y el despotismo; que siempre lucharon con impertérrito denuedo y ejemplar valor, que sacrificaron su bienestar y cuanto les pertenecía su vida reivindicar nuestros más sagrados derechos, ayer, como hoy y mañana, protestan y protestarán contra toda determinación que tienda a humillar a la más hermosa e importante ciudad del fronterizo Estado de Chiapas; contra todo paso que tenga por mira hundir en el aislamiento y aniquilación a la raza más privilegiada del territorio que, pese a enemigos y envidiosos, es, ha sido y será el núcleo de todas las combinaciones progresistas engendradas por la idea civilizadora, nutridas por la inteligencia y el saber y robustecidas por el poderoso brazo del trabajo y la riqueza, como vamos a demostrarlo de un modo incontrovertible.

Nosotros, dignos hijos de aquellos progenitores, no podemos ni debemos, so pena de eternos baldones de vergüenza e ignominia, borrar su sangre, ni desmentir su animoso espíritu y egregio civismo.

Abramos el gran libro de la historia, de ese viejo archivo donde están juzgados los pueblos y sus hombres, y demostremos una vez más, a todos los pueblos del orbe, que ni los rudos golpes de la autocracia y predominante arbitrariedad mellan nuestros afectos hacia el vastísimo y encantador valle HUEY-ZACATLAN donde felizmente se meció nuestra humilde cuna; ni el encendido fuego de las pasiones ni la impostura llena de oprobios y afrentas, amedrentan nuestro corazón joven aún para el sufrimiento y el dolor.

Perturbemos el sosegado sueño que muchos lustros hace adormece a vencedores y vencidos, a víctimas y verdugos, a patriotas y enemigos, trayendo a la memoria sucesos menos angustiosos que los presentes, y defendamos cual corresponde, escudados con las insignias del honor y el deber, nuestros más caros derechos, poniendo en lugar que merecen la verdad histórica y la de actualidad.

La situación de Chiapas es por demás aflictiva, azarosa y apremiante. No obstante la mentira, el engaño y la adulación con que obnibulan la realidad de los periódicos oficiales y semioficiales, entre ellos algunos de los que se emplean en aparecer imparciales, surge un rumor, óyese un clamoreo, en el fondo de pechos oprimidos se apagan quejas, se ahogan suspiros, se consumen alientos. ¡La desgracia, la ruina y la fatalidad están a las puertas del Estado! Si una mano salvadora no detiene sus avances, presto habrán extendido sus temibles y desastrosos dominios por doquier y entonces esta parte de la confederación mexicana, antes llena de vida y esperanzas, volverá a las épocas de su primitiva formación.

San Cristóbal Las Casas, pueblo heroico y valiente, grande y civilizado, que ha sido en más de tres siglos foco inextinguible de luz, saber y actividad; que rico industrioso y desinteresado, potente y generoso, guerrero y benigno, indulgente y hospitalario, siempre ha sabido impartir sus cuantiosos elementos a beneficio de los demás pueblos del Estado, no pierde sus deslumbrantes glorias, ni se marchitan sus auríferos laureles, ni se debilitan sus colosales fuerzas, ni mueren sus dulces y risueñas esperanzas sólo porque llegue a impregnarse su atmósfera con el hálito venenoso de la venganza y la envidia. Estamos para su defensa y nos sirven de apoyo más que la tierra firme de un continente, la justicia y la razón y con ellas la opinión pública.

Aun arrastrando peligros y acometiendo dificultades, sonará en el reloj del tiempo la ansiada hora de salvación, y con los trofeos de la magnanimidad y el perdón aparecerá vencedora y triunfante la hoy abatida y postergada capital de San Cristóbal Las Casas, porque la justicia le pertenece y "la verdad puede fatigarse pero no vencerse". Las dudas y los temores, las sospechas y las vacilaciones se disiparán de nuestro horizonte político, como llegada la estación invernal se disipa de nuestro espacioso cielo las nieblas.

Las sabias y fecundísimas enseñanzas del presente y el pasado nos ofrecen para el porvenir provechosas y saludables lecciones, que con afán y solicitud siempre sabremos estimar.

Nadie hay que con éxito seguro se oponga al prepotente impulso de las eternas leyes del destino.

El mundo ha tenido para transformarse y regenerarse sus espantosas hecatombes y sus horribles sacudimientos.

La humanidad camina incesantemente, cruza imponente y majestuosa las varias edades de la vida y 
buscando el ideal de su perfección, emprende cae y levanta y al fin corona sus designios.

El hombre viviendo en constante agitación y mirando a lo lejos el puerto de su felicidad, tras una laboriosa gestación de siglos, se afana y se esfuerza, lucha y combate hasta lograr la satisfacción de sus aspiraciones.

Así la augusta Ciudad de San Cristóbal Las Casas, para trasformarse y regenerarse más y más, pasará por mil contratiempos, atravesará el inmenso mar de las pasiones y odios políticos, emprenderá, caerá y levantará, pero al término de sus inquietudes y fatigas ostentará grande y orgullosa los emblemas de su envidiada predilección: Inteligencia y saber, valor y civismo, actividad y trabajo, poder y riquezas.

Dicho dejamos que hoy solo nos ocuparemos de la última traslación de los poderes del Estado a la ciudad de Tuxtla. Tal vez nos impongamos después la satisfactoria tarea de tratar de cada uno de los hechos que en la actualidad causan el descontento general, así como de impugnar los ataques que sobrevengan por esta defensa; pero en todo caso, aunque revivan rencores y renazcan rencillas, serenos, e impasibles y firmes en nuestro propósito, proseguiremos nuestra noble misión; porque sólo así las futuras generaciones no reprobarán nuestra indolencia ni nos culparán de fríos e indiferentes.

El Decreto relativo, que aún no aparece en el "Periódico Oficial" dice así:

SECRETARIA DEL GOBIERNO CONSTITUCIONAL DEL ESTADO LIBRE Y SOBERANO DE CHIAPAS.

Decreto número 8.- EL GOBERNADOR SE HASERVIDO

DIRIGIRME EL DECRETO QUE SIGUE:

EMILIO RABASA, GOBERNADOR CONSTITUCINAL DEL ESTADO LIBRE Y SOBERANO DE CHIAPAS, A SUS HABITANTES SABED: QUE EL CONGRESO DEL MISMO HA TENIDO A BIEN DECRETAR LO SIEGUENTE:

EL XVII CONGRESO CONTITUCIONAL DEL ESTADO LIBRE Y SOBERANO DE CHIAPAS, EN NOMBRE DEL PUEBLO DECRETA:

Art. $1^{\circ}$.- LA CIUDAD DE TUXTLA GUTIÉRREZ, SERÁ EN LO SUCESIVO LA RESIDENCIA DE LOS PODERES DEL ESTADO.

Art. $2^{\circ}$.- LAS OFICINAS QUE AUN NO SE HAN TRASLADADO, LO HARÁN CUANDO EL EJECUTIVO LO
DETERMINE ANTES DE LA CONCLUSIÓN DEL PRESENTEAÑO.

EL EJECUTIVO DISPONDRÁ SE IMPRIMA, PUBLIQUEY CIRCULE, DADO EN ELSALÓN DESESIONES ENTUXTLA GUTIÉRREZ A LOS NUEVE DIAS DEL MES DE AGOSTO DE MIL OCHOSCIENTOS NOVENTA Y DOS. Alejandro Rovelo-D.P.- Munuel T. Corzo, D.S.-Manuel Suárez, D.S.

Por tanto mando se imprima, publique, circule y se le dé el debido cumplimiento.-Palacio de Gobierno del Estado, Tuxtla Gutiérrez, Agosto once de mil ochocientos noventa y dos. EMILIO RABASA.- Al Ingeniero Virgilio Figueroa Oficial Mayor encargado de la Secretaría General del Despacho.

Y lo comunico a Ud. para su inteligencia y demás fines.

Libertad y Constitución. Tuxtla Gutiérrez, agosto 11 de 1892.- V. Figueroa.

Tal decreto es de trascendentales consecuencias: lo comprueba una tristísima experiencia, como lo demostraremos con irrefutables razonamientos según lo hemos ofrecido en otro lugar.

\section{CAPÍTULO II}

Reseñemos brevemente los beneficios que el Estado debe a su capital desde la fundación de ésta.

En el año de 1527 aconteció en Chiapas la segunda sublevación de indígenas, y después de sofocada por el capitán Diego de Mazariegos, salió éste en unión de Dn. Luis del mismo apellido y demás hidalgos a practicar un reconocimiento del territorio y pueblo de la provincia. A su regreso pasó por el valle de Jovel (según lo llamaban los naturales y Huey-Zacatlán los mexicanos), valle que había sido visitado por el capitán Luis Marín.

En vista de la ventajosa posición que el valle Jovel tenía, que siendo el mejor de todos los puntos reconocido, se hallaba en lo más céntrico de la Provincia, que estaba en medio de los pueblos indígenas más numerosos en habitantes que este era el lugar más conveniente para imponer a los aborígenes y evitar las sublevaciones tan 
frecuentes en aquella época, que el poder casi a igual distancia de todos los subordinados haría más fácil la acción civil, social y religiosa de Gobierno, llegando y cumpliéndose con regularidad de sus disposiciones que su temperamento era suave y benigno y su aspecto muy pintoresco y delicioso que estaba defendido de los vientos septentrionales por la larga cordillera que la resguarda al norte, formada por el cerro onIx; que sus terrenos demostraban ser muy fértiles; que abunda en él la piedra caliza y las maderas más propias para construir en él una Gran Ciudad, que regaba su vasta extensión doce fuentes y un río, que se encontraba deshabitado, y que al establecerse en él una población en nada perjudicaría a los indígenas de las poblaciones inmediatas, en atención a que sería muy difícil hallar otro punto que reuniera mayores comodidades, se determino fundar, en dicho valle, la Capital de Chiapa, con el nombre de Villa Real de los Españoles, lo que se verificó el 31 de marzo de 1528. Los nombres que a continuación ponemos son los que acompañaron al Sr. Capitán Diego de Mazariegos en su expedición a Chiapas, y con excepción de los que murieron en el sitio de Soctón, los restantes son con los que se fundó Ciudad Real: Capitán Dn. Diego de Mazariegos, Luis de Mazariegos, Baltasar Guerra, Juan Enriquez de Guzmán, Luis de Luna, Francisco Gil, Balde Villacastín, Fernando de Zúñiga, Francisco Ortez de Velasco, Pedro de Castillo, Pedro González, S. Pedro de Panco, Franciso Sáenz Marroquín, Pedro de Orozco Acevedo, Juan Gómez de Sotomayor, Diego Martín de la Zarca, Diego Holguín, Pedro de Solórzano, Juan de Orduña, Andrés de la Tovilla, Juan Méndez de Sotomayor, Fernando Lozano, Juan Muñoz de Talavera, Juan Vera, Cristóbal Morales, Cristóbal de Paradinas, Gonzalo Sobrino, Antonio de la Torre, Diego de Villareal, Alonso de Aguilar, Diego Hernández Calvo, Bartolomé Marroquín, Luis Bengifo, Alonso Sarios, Cristóbal de Comontes, Alonso Martín Granado, Francisco Solís, Esteban de Solís, Gonzalo Solís, Juan de Escobar, Bernandino de Caccia, Francisco Samartín, Rodrigo de Salamanca, Miguel Quintero, Diego García, Rodrigo Sánchez, Juan de Alcántara, Diego de Calicoche, Pedro Moreno, Antonio Sánchez, Francisco Domínguez, Gonzalo de Zea, Pedro de Santiesteban, Pedro Gutiérrez, Francisco Marticote, Pedro Gentil, Martín de Guecho, Francisco Moreno,
Benito de Albacete, Alonso de Rivera, Gaspar de Santacruz, Diego de Ortega, Diego Baiza, Pedro Ramírez, Martín Griego Negrete, Juan Arandía, Juan de Olmedo, Juan Sánchez, Bernandino de Valderrama, Fernando de Villaviciosa, Juan de Vargas, El Capitán Luis Marín, Martín de Lorca, Alonso García, Juan de Potrillo, Fernando Ortez de Velasco, Diego Suárez, Maesse Jerónimo y maesse Juan Bostero.

El nombre de Villa Real fue cambiado en otros diferentes; pero informado el Emperador Carlos V. por el Capitán Diego de Mazariegos de los muchos servicios que esta población prestaba a la majestad divina y humana, a petición del mismo Mazariegos, le concedió el título de Ciudad y mandó por cédula de 7 de julio de 1536 que se llamase y reconociese por Ciudad Real.

La nueva Ciudad Trató de corresponder dignamente a la merced que se le había hecho, y dio principio a su misión civilizadora en bien de todos los habitantes de la Provincia de Chiapas. Lo primero que se hizo fue ponerse de acuerdo el Ayuntamiento con los frailes dominicos y encomenderos para hacer que los indígenas se redujesen a poblado, porque una gran parte de ellos estaba diseminada por los montes y así era imposible que diera buen resultado cualquiera medida que tuvieran por objeto sacarlos de estado de barbarie en que se encontraban.

A medida que la población aumentaba el tiempo corría, Ciudad Real redoblaba sus esfuerzos en provecho de la provincia, trayendo de Europa, de la Isla de Cuba y de las Canarias, los animales y semillas hasta entonces conocidos y de más utilidad en el antiguo continente, como son los ganados, vacuno, caballar, lanar, cabruno y porcino; los asnos, los perros los gatos y los conejos de Castilla y de Austria, el pavo real, la gallina, la paloma de Castilla, el ruiseñor, el canario amarillo, el tordo de las alas encarnadas, etc., etc; el trigo, la cebada, el garbanzo, la caña de azúcar, la uva y muchas semillas de árboles frutales y de horticultura.

El espíritu emprendedor de este pueblo no descansa y busca por cuantos medios está a su alcance el engrandecimiento de la Provincia. Al efecto, enviaba a las personas más entendidas en la ciencia geológica, agrícola y accesoria, a sus distintas subelevaciones, para que hagan la clasificación de las tierras, a fin de no 
equivocar el cultivo a que deban dedicarse, principalmente aquellas que fueron más aparentes para la grana, el cacao y el índigo, que en aquel tiempo eran granos de mucha estimación en los mercados Europeos; y para examinar los causes de los ríos, los aguajes y los valles que, por su posición los unos, y por su abundante pastura los otros, fueran más a propósito para la propagación de la ganadería. Establece las mejores haciendas que hasta hoy existen en el Estado de Chiapas, como luego veremos; manda las primeras colonias por todo el territorio: las protege y trabaja sin cesar por su progreso y mejoramiento, porque sin disputa Ciudad Real es la cuna de la generalidad de las poblaciones de ladinos que existen en el hoy llamado Estado Libre y Soberano.

Para la prosperidad y adelanto de la antigua Provincia, Ciudad Real no sólo ha dado sus capitales, sino también lo más precioso de su ser, sus hijos. Esta población debía tener hoy 200000 habitantes, y no los tiene ¿por qué?, porque desde los primeros tiempos de su institución, se han diseminado para fundar la generalidad de los pueblos de ladinos que hoy existen en el Estado, como dejamos dicho, son colonias de Ciudad Real, las siguientes poblaciones que nombramos en orden a su posición geográfica, por convenir así a nuestro relato: Comitán, San Bartolomé, Chiapa, Tuxtla, Ocosingo, Chilón, Yajalón, Simojovel, Jitotol, Socoltenango, Pinola, Teopisca, Huistán, Tenejapa, San Andrés, Guaquitepec y otras de menos importancia.

Aquí es el lugar de que presentamos la nómina por lo que consta de datos escritos y tradicionales, de las familias más visibles que de Ciudad Real salieron para fundar las principales colonias que hemos hecho relación. Para fundar la colonia del pueblo de Comitán (BALUNCANAN le llamaban los naturales, NUEVE LUCERos) hoy ciudad de este nombre, cabecera del departamento más rico y más notable de todo el Estado, por la sobriedad, laboriosidad e inteligencia de sus vecinos, principalmente por el buen sentido práctico que los distingue; pues sin perder el tiempo en discusiones inútiles, han sabido resolver su demarcación territorial los dos problemas económicos propuestos por el sabio e inmortal Víctor Hugo "Crear la riqueza pública y saberla distribuir”, porque Comitán es el punto donde mejor distribuida está la riqueza y la propiedad.
Por alcanzar tan loable fin, es lo que más honor da a sus fundadores y procurar la propagación de los ganados caballar, vacuno y lanar, en sus extensos valles, salieron de la Capital de la Provincia los Cabrera, los Gordillo, los Escandón, los Arguello, los Albores, los Domínguez, los Culebro, los Román, los Rivera, los Aguilar, los Ruiz, los Coello, los Villatoro, los Guillén, los Mandujano, los Figueroa, etc., etc.

Para fundar las haciendas del Valle Custepeques y colonizar el pueblo de San Bartolomé, hoy ciudad, salieron de la capital, los Velasco, los Gorriz, los Tovilla, Ios Cancino, Los Borraz, los Gordillo, Ios Ocampo, los Montes, los Peña, los Cristiani, etc,. etc.

Para fomentar la industria azucarera, la ganadería y el cultivo del añil fueron a la Villa Real de los indios de la Real Corona, hoy ciudad de Chiapa de Corzo, los Guerra, los Camas, los Coutiño, los Zapata, los Escobar, los Grajales, los Aguilar, Ios Flores, los Córdova, los Morales, y además Frailes dominicos de la Capital de la Provincia, fundaron las mejores haciendas del valle “La Frailesca” y las poblaron de africanos.

Para fundar la colonia establecida en la ranchería de indios Zoques, conocida con el nombre de Tul-lum (Tullum en lengua Tzeltal dice Tierra del Conejo) hoy ciudad de Tuxtla, salieron de Ciudad Real los Olaechea, los Velasco, los Maldonado, los Esponda, los Palacios, los Zorrilla, los Sanjuan, los Camacho, los Flores, los Espinosa, los Farrera, los Madrigal, los González, los Balboa, los Moguel, Ios Figueroa, los Aguilera, los Cruz, los Bustamante, los Marín y de entre estas familias los más acomodados crearon las mejores haciendas de los valles de Jiquiipilas y Cintalapa, dedicándose con especialidad a la ganadería y al cultivo de la grana y del índigo.

Para fundar la colonia en el pueblo de Nación Tzeltal Hucutzín, hoy Villa de Ocosingo, y fomentar por el rumbo de Oriente, la labranza y la ganadería, salieron los Zenteno, los Solórzano, los Trujillo, los Maldonado, los Parada, los Martínez y además los dominicos de Ciudad Real establecieron las haciendas de la Frailesca en Ocosingo.

Para fundar la colonia del pueblo de Chilón, en otro tiempo cabecera del Departamento de este nombre hoy villa, y fomentar en él la industria azucarera, fueron los Guillen, los Estrada, los Solano, los Lara, los Astudillo, los Guirao, los Cruz y otros. 
A fin de no cansar la atención de nuestros lectores, ponemos punto en este respecto, manifestando que la villa de Simojovel fue fundad por vecinos de las secciones de Cerrillo y Mexicanos de Ciudad Real, para implantar el cultivo de tabaco y café.

Las demás colonias que dejamos enumeradas fueron ensanchándose paulatinamente por las diferentes secciones de que se ha compuesto la mencionada capital de la Provincia, pues sus vecinos propenden a viajar continuamente y emigran muchas veces para proporcionarse mejores terrenos y mayores elementos, evitándose de las molestias del servicio militar y de los tequios consiguientes, el vasallaje de los gobiernos, unos más que otros imponen sobre los habitantes que tienen más inmediatos.

La Ciudad Real no sólo extendió sus beneficios a los pueblos que estaban sujetos a la jurisdicción del Gobierno, sino que llevó también sus bienhechoras tendencias fuera de este círculo, y por medio del cura Dn. M. José Calderón procuro que llegasen hasta los Lacandones. El referido cura entró en la relación con estos y al observar su docilidad y mansedumbre, y entendió también de los vestidos e instrumentos de labranza que más gustaban, informó de todo al intendente Dn. Agustín de las Cuentas Zayas, quien fue para el Palenque con el objeto de informarse mejor de las posibilidades de buen éxito con que la empresa contará. Persuadido por relatos del Cura Calderón y de otras personas de que no se debía perder tiempo, facilito la suma de mil pesos para comprar regalos con los que hubiera de atraerse a dichos indígenas.

Hechos los preparativos para la expedición, se pusieron en marcha hacia las montañas en que habitaban los lacandones en el año de 1790, el cura Dn. M. José Calderón y otras personas; y habiéndolos encontrado, el mismo cura agasajó y persuadió de que debían vivir en sociedad y de las ventajas que reportarían con esta medida., porque diseminados como estaban en los bosques, les era difícil defenderse hasta de las mismas fieras. Aquel virtuoso ministro consiguió persuadirlos, y con cuarenta familias que reunió fundó el pueblo de San José de la Gracia Real, y se volvió al punto de su resistencia.

La ciudad Real también ha cuidado de sus vías de comunicación. Sin contar otras de menos extensión, hacemos constar aquí que promovió la apertura del camino que en aquella época se creyó de más importancia para el desarrollo del comercio entre Mérida y Guatemala, tocando las subelevaciones del Palenque, Chilón y Comitán y pasando por los montes seculares de Bachajón.

Los pueblos del Estado, no sólo deben a su capital su desarrollo, progreso material y riqueza, sino que también su adelanto y mejoramiento moral e intelectual.

En aquellos tiempos el colegio de los Jesuitas de Jesús Crucificado estableció las primeras Escuelas de enseñanza primaria. Los reverendos padres dominicos y franciscanos en cumplimiento de la cédula de 7 de junio de 1530, establecieron otras escuelas en las que también se enseñaba la lengua Castellana a los indígenas.

La ley 18. título primero, libro sexto de la Recopilación de las Indias hizo extensivo este precepto a los sacristanes de todas las iglesias parroquiales y el Ayuntamiento de Ciudad Real desde luego inauguró y estableció la suya; pero el plantel que permaneció por más tiempo fue el fundado con el capital de cuatro mil pesos por Dn. Nicolás Velasco Campo, que el rey de España puso al cuidado del mismo Ayuntamiento. Dicha escuela dejó de existir porque dispuso el Gobierno del Estado en 1838, de los cuatro mil pesos sin que hasta hoy haya repuesto.

Las escuelas que en la actualidad tienen bajo su inspección el H. Ayuntamiento de San Cristóbal de Las Casas, están sostenidas con otra clase de rentas.

La enseñanza secundaria fue atendida con alguna solicitud y antes de que en ninguna otra parte en Ciudad Real. En sus conventos se establecieron primero Cátedras de Latinidad, Filosofía, Teología moral, y Teología escolástica. En 1678 se fundó el Colegio Seminario por el IImo. Sr. Dn. Marcos Bravo de la Cerna y Manrique, quien no sólo sostuvo las Cátedras antes establecidas en los conventos, sino que además de doce becas de gracia, admitió alumnos internos de las Provincias de Chiapas y Tabasco.

En 1826, por decreto del Congreso del Estado, se fundó la Universidad Literaria que más tarde por nuevas disposiciones, ocupó el mismo edificio en que estaba el antiguo Seminario, y además de darse las Cátedras antes 
Víctor Manuel Esponda Jimeno

enumeradas, se establecieron las de Derecho Civil y canónico y medicina.

Corriendo el tiempo, a Universidad ya dotada de otras muchas cátedras pasó a ser Instituto Científico y Literario y últimamente Instituto de Ciencias y Artes; cuando este plantel, el primero en Chiapas por diversos ramos del saber que en él se enseñaban por su crecido número de alumnos del Estado y fuera de él, por sus fondos no despreciables, caminaba en progreso de año en año, no ha mucho que fue suprimido, lo que se esperaba por el actual Gobernador Sr. Lic. Emilio Rabasa. De los establecimientos de enseñanza primaria y secundaria de que hemos hecho mención, para todo el Estado de Chiapas y aún fuera de él, hasta servir en el extranjero, Pedagogos, Bachilleres, Agrimensores, Ingenieros, Escribanos Públicos, Abogados, Médicos, Sacerdotes, Obispos, Doctores, etc., etc.

Todos estos beneficios y otros muchos que no enumeramos, porque son bien conocidos y porque no queremos cansar la atención de nuestros lectores ¿Cómo se han correspondido a la Ciudad Real por su colonia? ¡triste es decirlo! Con excepciones que nunca faltan, la correspondencia ha sido una negra ingratitud, un odio reconcentrado, una envidia insaciable, un innoble deseo de preponderar a toda costa, olvidando todo bien y pagando tanto beneficio, como responde aquella especie de serpientes, que al ser dadas a la luz, lo primero que hacen es devorar a la madre que les dio el ser.

Hoy que el Sr. Emilio Rabasa acaba de trasladar los poderes públicos de su antigua residencia a la Ciudad de Tuxtla que sacándolos del centro del Estado los lleva a un punto inmediato al desierto que se extiende hasta Oaxaca, preguntamos para qué se nos designa ¿qué población del actual Estado de Chiapas tiene los méritos de Ciudad Real? ¿qué otra población de Chiapas reúne más condiciones y tiene $u$ ofrece mayores elementos que San Cristóbal Las Casas para seguir impulsando el progreso material, moral e intelectual en bien de muchos pueblos indígenas que rodean el centro? Creemos sin riesgo de equivocarnos, que en todo nuestro territorio no hay pueblo, villa o ciudad con quien se pueda comparar en todo sentido y aún hacemos más amplia nuestra consideración, diciendo que tal vez en toda la Nación Mexicana, con dificultad habrá otra ciudad como ésta que haya prestado servicios de tanta magnitud e importancia a la civilización y al progreso de las masas y pueblos de su derredor.

\section{CAPÍTULO III}

Al hacer la narración histórica de los servicios que en diversas épocas ha prestado la ciudad que fundó el Capitán Diego de Mazariegos a todos los habitantes de Chiapas, nuestro objeto no es sólo hacer resaltar los méritos de la localidad, nos proponemos aun en demostrar la necesidad que hay de que los Poderes des Estado residan en su seno por razones de conveniencia pública para todo el territorio y sus moradores. Esta necesidad ha sido reconocida por los gobiernos que hemos tenido en el largo período de más de tres siglos, como pasamos a demostrarlo.

La primera audiencia de México tuvo jurisdicción hasta sobre Guatemala por instrucciones que recibió de Valladolid el 5 de abril de 1528, y como Chiapas era un punto intermedio, quedó sujeto a la misma. Desde esta remota fecha nos comenzaron a venir de México las autoridades que nos han gobernado, y de entre ellas no hubo un solo Alcalde Mayor que hubiera desconocido la conveniente y ventajosa situación de Ciudad Real, como Capital de la Provincia.

Por real cédula de 20 de noviembre de 1542 se creó la audiencia de Centroamérica con el nombre de Confines, y la componían las provincias de Honduras, Nicaragua, Chiapas, Tabasco y Yucatán. Habiendo formado Chiapas por tal disposición, parte de la Capitanía General de Guatemala nos continuaron viniendo de este punto los Alcaldes Mayores y demás autoridades, todas las personas imparciales y de reconocida honradez y no obstante los cambios y modificaciones introducidas por los hombres y costumbres de aquellas épocas, Ciudad Real por ningún motivo dejó entonces de ser Capital de la Provincia.

En 1790 se erigió en Intendencia la Alcaldía Mayor de la Provincia de Chiapas, y de la misma manera nos continuaron viniendo de España y Guatemala los Intendentes y Asesores y otros empleados públicos, sin que haya noticia alguna de que ninguno de éstos haya 
siquiera pensado sacar el Gobierno de la Provincia de su primitiva Capital.

Muy sabido y reconocido es el influjo que la autoridad eclesiástica ejercía en todos los negocios civiles en los tiempos de que vinimos hablando. La generalidad de los Obispos que han gobernado la Diócesis en Chiapas, han sido personas muy ilustradas; pues entre ellos se enumeran Licenciados, Doctores graduados en alguna Universidad, Padres, Maestros jubilados en algún convento, etc. y ninguno de ellos en más de sesenta lustros dispuso separar el centro de sus operaciones, de su régimen y gobierno de Ciudad Real.

Aquí es preciso que abramos un paréntesis para decir que entre esa multitud de Jefes y Prelados eclesiásticos figura con timbres de gloria y renombre el segundo Obispo de Chiapas, el conspicuo filántropo, el egregio benefactor Fray Bartolomé de Las Casas, el inmortal protector de la raza primitiva, el abnegado perseguidor de los abusos de las autoridades civiles, ¿qué diera Chiapas por tener en la actualidad otro Fray Bartolomé de Las Casas, hoy que pesan sobre el Estado más contribuciones que la que paga el oprimido pueblo del imperio Turco; hoy el gobernador Lic. Emilio Rabasa, con la imposición de nuevas y gravosas contribuciones municipales y fiscales, está arrebatando a los padres de familia el mendrugo miserable con que mantienen a sus hijos, hoy que como nunca se ha estado exigiendo a los pueblos indígenas y ladinos en dinero efectivo la anticonstitucional prestación de trabajos personales; que el hambre y la pobreza azotan a un gran número de familias, que se están manteniendo con hojas y flores de milpa; hoy que a media noche se asaltan en sus hogares a hombres y mujeres de los pueblos de Oxchuc, Huistán, Tenejapa, Zinacantán y otros, que después de encarcelados, al toque de marcha y arrebato, se unen mujeres y hombres indistintamente para que amarrados vayan a prestar trabajos forzados a la finca Peña Flor y al lugar de empresas de madera, que distan más de 158 kms. del punto de su residencia; hoy en fin que el letrado y novelista Gobernador se está haciendo célebre por su inhumanidad y sus disposiciones descabelladas, que de día en día hunden al Estado de desgracia en desgracia, necesitamos de otro ilustre Las Casas, que como aquél nos traiga otro juez visitador como Gonzalo Hidalgo Montemar, y de cuenta ante quien corresponda de la aciaga situación en que se halla el antes floreciente Estado de Chiapas.

Muchos de los Alcaldes Mayores e Intendentes recorrieron el territorio de la Provincia, y entre éstos contamos a Dn Juan B. Garracín Ponce de León que describió a Chiapas y a Dn. Agustín de las Cuentas Zayas; y podemos asegurar que, tanto aquellos personajes, como los Obispos que siempre y sin excepción practicaban minuciosamente sus visitas diocesanas, todos, aprobaron fuera la residencia de los Poderes en Ciudad Real. Notable es por mil títulos que en esa larga lista de Hombres todos tan prominentes cuanto entendidos en la ciencia del bien gobernar, no se registrase uno solo que en el transcurso de más de tres siglos haya desconocido las razones de bien procomunal, que obligaron a Mazariegos a fundar la Capital del la Provincia en el espacioso y encantador valle “JOveL”, ni hay dato alguno de que hayan encontrado otro que dada la situación geográfica de la Provincia de Chiapas, le superase en posición y condiciones para cambiar la residencia de los Poderes Públicos.

En septiembre de 1821 proclamó Ciudad Real la independencia de la Provincia de la obediencia del Gobierno español y destituyendo en consecuencia de su alto puesto al Intendente Dn. Juan Batres. En 14 de septiembre de 1824 la Provincia se incorporó a la Nación Mexicana y en todas las distintas épocas en que el sistema central ha imperado en la nación, de México y otros puntos han venido Gobernadores, Comandantes, Coroneles y Generales que hemos tenido de mandatarios; y en esa serie de jefes militares, como los Alcaldes Mayores, Intendentes, Obispos, etc., de que hemos hablado, todos hombres imparciales, y exentos del malentendido amor localista, apasionado impolítico, por no ser vecinos de Chiapas; todos independientes en su modo de opinar y disponer por no estar subyugados al espíritu del partido, antipatía ni venganza; ¿cómo es que ninguno de ellos pensó en sacar los Poderes Públicos del Centro del Estado, para trasladarlos a la ciudad de Tuxtla, en caso de que este punto excéntrico hubiera sido más conveniente para el gobierno de los pueblos? Según procede el actual Gobernador Sr. Emilio Rabasa, debe deducirse que ese largo catálogo de Gobernantes, Jefes Militares, Mandatarios, etc., antiguos y modernos, 
Víctor Manuel Esponda Jimeno

que han regido los destinos de Chiapas, nada vale, que aquéllos estaban en un error, no atinaron, se hallaban equívocos, y que el es el único que ha acertado promulgando su decreto de 9 de agosto del presente año, en el que manda que en lo sucesivo la residencia de los Poderes del Estado será la pequeña ciudad de Tuxtla ¡Oh Témpora! ¡Oh Mores! exclamaba el orador romano, admirándose y levantándose de los tiempos y costumbres de su época; pero nosotros hoy mucho más lamentamos y nos admira la ligereza y precipitación del joven Gobernante Rabasa al proceder con el calor de su mocedad y guiado de enojos y rencillas en un asunto sumamente delicado, sin antecedentes ni bases cimentadas, cual niño experto y novel mandarín, que sin conocimiento de causa, quiere enmendar la plana a esa pléyade de hombres, sabios, políticos, militares, independientes, demócratas e imparciales, que desde la conquista hasta nuestros días, nunca pensaron en trasladar los Poderes del Estado de su antigua Capital a la ciudad de Tuxtla.

\section{CAPÍTULO IV}

El Gobierno es de los pueblos y no los pueblos son del Gobierno, es decir, los hombres asociados con el uso de su soberanía nombran sus mandatarios, no para quedarse de instrumentos y autómatas, o seres maniatados, sino para que dirija sus destinos con el desprendimiento, imparcialidad e integridad que demanda tan delicada comisión; pero los mismos, el gobernante no puede subordinar el interés público al particular, y esto es precisamente lo que el Sr. Lic. Rabasa ha hecho al mandar expedir y promulgar el decreto de 9 de agosto ya citado; pues la única razón que alegar puede es la de querer vivir en el lugar en que ha nacido porque la apertura de camino carretero de Tuxtla a Tonalá, la canalización del río de Chiapa y cualquier otra mejora proyectada, todo, todo es un mero y mal disimulado pretexto, supuesto que estos trabajos se pueden y deben encomendar a uno o más ingenieros y a algunos capataces.

El Gobernador ha sido electo para regir los destinos del Estado; para manejar cual diestro piloto la gran nave política de Chiapas, para cumplir con la Constitución Federal y Local y con las leyes que de ambas emanen; para vigilar por su observancia con ojo atento y hacer que todas las autoridades departamentales les den cumplimiento y exacta aplicación; y como el Sr. Lic. Rabasa pretenderá cumplir con estos ineludibles deberes, separándose del centro de todos los pueblos, situándose en un extremo del territorio y dejando a su espalda la mayor parte de los departamentos. Hemos dicho el centro porque la antigua Capital del Estado de donde el joven Gobernante acaba de alzar su vuelo, está rodeada de muchos pueblos y todos los Departamentos, y dejamos asentado que se ha situado en un extremo del Estado; porque el Departamento de Tuxtla es el último que tenemos al poniente, y colinda con Oaxaca por el cerro de Chilillo más allá de la Jineta habiendo de por medio un desierto.

Al demostrar la centricidad de la Capital de Chiapas y el Departamento al cual corresponde, de paso diremos que el nombre de Ciudad Real, que le dio el Emperador Carlos V., corriendo el tiempo se le cambió por el de San Cristóbal, según decreto de Congreso del Estado de 27 de julio de 1829 y por otro decreto expedido en 1846 se llamó como hasta hoy San Cristóbal Las Casas.

Al principio de esta narración dijimos que los fundadores de la Capital del Estado de Chiapas, al colocarla en el valle allí descrito, tuvieron entre otras razones de conveniencia pública, la centricidad del lugar, porque hallándose en tan ventajosa situación, como ninguno lo negará, la acción del Gobierno impartida con regularidad por todos los ámbitos llegaría oportuna y fácilmente a todos los pueblos de su mando. Lo demostraremos.

Un ramal de la Sierra Madre forma la mesa central del Estado de Chiapas y en medio de ésta se encuentra el valle Jovel, a los 2104.16 metros sobre el nivel del mar hallándose en el centro de dicho valle la ciudad de San Cristóbal de Las Casas.

La figura territorial del Estado es la de un polígono irregular, y a pesar de tener ésta muchas líneas quebradas y sinuosas, la capital está lo mejor que pudiera situarse en el centro de Chiapas, y tan bien colocada que dada la posición geográfica, no trepidamos en asegurar que no hay otro punto mejor que éste, lo que hace comprender que con razón y buen criterio así lo reconocieron nuestros antecesores. 
Para aclara más este punto, indicaremos las distancias según el itinerario más común, hay de San Cristóbal Las Casas capital del Estado de Chiapas, a las poblaciones que se hallan situadas en los ángulos más salientes del polígono ya mencionado.

DeSan Cristóbal Las Casas al Este, hasta las monterías del Desierto de la Soledad (Lacandones), 272 km.; al Nordeste, hasta Catazajá, 247 km.; al Nordeste por Pichucalco, 202 km.; al o.s.s. hasta la aduana marítima de Tonalá, 232 km.; al sur hasta Tapachula, tomando el camino de la Sierra, 293 km.; al S.E. hasta Nentón 172 km.; como se ve, los puntos más salientes del polígono son las monterías y Tapachula, y en cuanto a los demás con poca diferencia, están a igual distancia a pesar de la irregular figura del territorio de Chiapas.

Al Departamento en que ha estado la Capital de Chiapas, se le ha llamado, con muy sólidos fundamentos de todos conocidos, del Centro, porque queda en medio de los demás departamentos (y porque queda en medio de ellos) y como ninguno otro colinda con varios de éstos: al Oriente con el Departamento de Chilón, y al Norte, con el de Simojovel; al Poniente con los de Mezcalapa y Chiapa, al Sur con los de la Libertad; y al s.E. con los de Comitán. Estos Departamentos como el del Centro, son los más poblados de indígenas y necesitan por lo mismo de la presencia inmediata del Gobierno.

Queda bien demostrado que San Cristóbal Las Casas es el punto más céntrico del Estado, en el que han existido y deben continuar existiendo los Poderes de Chiapas por conveniencia política y notoria, y por necesidad política y social para atender al buen gobierno, orden, desarrollo y adelanto de los pueblos en todo sentido, y que ningún gobernante, que no haya sido de Tuxtla, desconocido a contar desde las épocas más remotas.

Otras razones apuntadas al principio que el Capitán Mazariegos tuvo para fundar la capital de la Provincia en el Valle de Jovel, fue hallarse la mesa central muy poblada de indígenas, que necesitan de ser vigilados muy de cerca, para evitar las frecuentes sublevaciones y además lograr que mudasen de costumbres rebajando por su civilización y mejoramiento, según las exigencias de cada época.

Por desgracia en esta raza desdichada nótanse aún hasta la fecha las necesidades y hay los mismos fundamentos de otros tiempos, y no vemos legal, humanitario ni acorde con el espíritu ilustrador del siglo, que no sólo se desampare al Departamento del Centro, que es donde existen más pueblos de indígenas en número nada despreciable, sin que se ahuyentan y remontan con la disposición oficial de sorprenderlos a la media noche y llevarlos presos, ligados de las manos, con la condición de animales a trabajos forzados del camino que conduce a Tuxtla, y a empresas particulares, obligándolos a que abandonen su domicilio, sin justa remuneración, por tiempo limitado, con mujeres que no son las de cada uno, sino las que se les arrimen al arbitrio y sin más ley que el capricho y el despotismo. Atentados son estos que no se vieron ni en tiempo de los conquistadores.

El Departamento del Centro tiene ochenta mil habitantes, los que en su mayor parte son indígenas. Esta sola circunstancia es un motivo bastante poderoso para que el gobierno deba permanecer en su seno, porque los Poderes tienen que estar donde hayan más individuos a quienes gobernar, dirigir, reprimir, educar, civilizar e ilustrar, y en indiscutible que en ningún punto del Estado encontraría el Sr. Lic. Rabasa tan vasto campo para poder desarrollar sus dotes intelectuales, como el expresado Departamento del Centro.

El temor de las sublevaciones indígenas subsiste en pié, y esto lo prueba la última que hemos tenido, promovida por el pueblo de Chamula en el año de 1869. No podemos creer que el gobernante Sr. Lic. Rabasa haya olvidado esa guerra de castas, ni que ignore los males que causó al Estado y al erario Público. Los hechos hablan más alto que la difusa palabrería estampada en el papel y que los ideales del Sr. Rabasa se haya forjado en sus concepciones intelectuales o inventado para engañarse así mismo o engañar a los cándidos, poniendo borrones a la historia, ofendiendo a sus comitentes y dando un paso tan impremeditado como peligroso e impolítico.

Don Juan Ortega revolucionó en el Estado por largo transcurso de ochos años; y en 1863 la paz pública estaba seriamente amargada en Chiapas, por lo mismo que en toda la Nación Mexicana. Para que nuestro gobierno pudiera restablecerla en el Estado y evitar que sus empleados y servidores cayeran prisioneros en los repentinos ataques que Ortega daba a la población, 
buscó un lugar seguro donde la distancia e inconvenientes del terreno lo pusieran al abrigo de aquellos ataques, y para ello eligió la ciudad de Tuxtla, la que por estar situada en la banda opuesta del río Grijalva, prometía entonces mejor asilo.

Con tal motivo y en épocas tan críticas y turbulentas, se trasladaron los Poderes Públicos del Estado a la ciudad de Tuxtla, en junio del año antes citado de 1863, permaneciendo en esta población y en la actual ciudad de Chiapa de Corzo, hasta después de la pacificada Nación Mexicana y cuando ya estuvo libre de los disturbios que le ocasiono la azarosa guerra de intervención.

Retirado el Gobierno de su antigua capital asomaron como ya sucede hoy, gavillas de malhechores por la frontera de Comitán, y los vecinos de Chamula y otros pueblos observaron que el gobierno, que tantas veces les había impuesto respeto se encontraba ochenta kilómetros más distante del lugar en que constantemente había residido; que el caudaloso Grijalva impedía la comunicación con aquél, y que no estaban inmediatamente vigilados. En vista de estas ventajas y bonancibles circunstancias para ellos, prepararon su nueva sublevación que estalló con más horror y encarnizamiento en junio de 1869; y se dedujo con la lógica de los hechos, que la razón que había habido de que el Gobierno existiera en San Cristóbal Las Casas para imponer respeto a los numerosos pueblos indígenas de la mesa central, aun estaba, como hoy lo esta, en toda su fuerza y vigor.

El decreto de junio de 1863, fue expedido por causas de conveniencia general y con muy justos motivos, nos trajo la sangrienta sublevación de 1869; de donde es obvio deducir que el decreto del 9 de agosto del corriente año nos traerá mayores males, peores resultados y funestas consecuencias; porque si el primero, siendo justificado y propio de aquellos tiempos apremiantes, nos acarreó una sublevación que asoló a muchos pueblos del Centro, el segundo, siendo absurdo y desatinado, habrá de labrar la desgracia y ruina de la extensión territorial más importante del Estado.

De lo expuesto se viene en conocimiento de que el decreto que con poco acuerdo votó el Congreso del Estado el 9 de agosto último, y que solo fue para complacer al Sr. Rabasa. no tiene razón de ser y es improcedente porque favoreció a una minoría, perjudica a todo el Estado. Los representantes de los pueblos no están para hacer complacencias cuando éstas dañan y gravan a sus representados.

Los representantes no tienen más facultades que las que le confieren sus representados; y qué las facultades pudieran dar éstos en el caso de que se trata, cuando la traslación de Poderes fue maquinada en Palacio de la noche a la mañana?, cuando no hubo tiempo de que los pueblos manifestasen su aquiescencia en un asunto de tan vital importancia y de gran trascendencia; cuando varios de los Diputados de actual Congreso no son conocidos pero ni de nombre de los habitantes que representan; cuando hay quienes carecen de opinión y de voluntad propias para ante la terrible influencia del que gobierna?.

No hay para que rebajar la dignidad ni andar dañosas complacencias si el Sr. Rabasa no le conviene estar donde la voz popular lo manda, donde las necesidades sociales lo exigen, puede separarse del puesto, con lo que haría un positivo servicio al Estado y aun se haría un bien a sí mismo, porque su falta de dotes administrativas y sus impremeditadas determinaciones, han causado más mal y desconciertan a todo el Estado en pocos meses, que cuando con rudeza, odio y venganza hubieran hecho los Gobernadores en veinte años.

\section{CAPITULO V}

El decreto de 9 de agosto del presente año, que con justicia combatimos, además de ser absurdo, es también ilegal, porque el Congreso del Estado, siempre que legisle, debe obrar en armonía y de acuerdo con las leyes federales. El supremo decreto de 22 de julio de 1867 mando que los Gobiernos de los Estados, que, con motivo a la guerra de intervención, se hallaran entonces separados de sus antiguas capitales, volvieron a ellas, decreto que es tanto más obligatorio, cuanto que el Art.. 126 de la Constitución Federal proviene que a esta ley suprema y a las del Congreso de la Unión que de ella emanen, deberán ajustarse a todas las autoridades de los Estados; y si tratándose de la mejor estabilidad de los Poderes de cada una de las partes integrantes de la 
Nación de su seguridad y bienestar, el Congreso General tiene dispuesto que los Gobiernos están en sus antiguas Capitales, es concluyente que la Legislatura de Chiapas, al haber dispuesto trasladar a Tuxtla los Poderes del Estado, sin más necesidad que el gusto del gobernante, ha legislado contra la disposición suprema antes citada y se ha opuesto abiertamente a lo que ella previene.

Mas estando en la conciencia de todos que el decreto de 9 de agosto, de que con insistencia nos hemos venido ocupando, perjudica a los intereses generales del Estado; que aquél es inconveniente, toda vez que se dio por pura complacencia, esto es, para facilitar al Sr. Rabasa su permanencia en Tuxtla, en donde tiene el asiento de sus negocios privados, el de su familia, favoritos y allegados; que siguieron la tortuosa marcha política de Sr. Rabasa habría de admitirse que la residencia de los Poderes Públicos ha debido estar en la frontera de Comitán, en Tapachula, Tonalá Oaxaca y en otros puntos del interior cuando gobernaron los señores José Pantaleón Domínguez, Sebastián Escobar, Diego Betanzos, José María Ramírez, Carlos Borda, José María Villasana, etc., por el hecho de que estos ciudadanos no eran de San Cristóbal Las Casas; a la manera que los señores Generales Porfirio Díaz y Manuel González han debido situar la capital de la República en Oaxaca y Tamaulipas que es inaceptable subordinar el interés público al particular; que la inmotivada traslación de los Poderes de su antigua capital San Cristóbal Las Casas, a un lugar excéntrico, solo ha sido para crear discordias y divisiones entre partidos, que no hay prudencia ni cordura en sacar dichos Poderes del Departamento más céntrico y popular del Estado, para colocarlos en uno de los más despoblados que hallándose los Departamentos de Tuxtla y Tonalá en un extremo del territorio y a la banda izquierda del Grijalva, quedan distantes y divididos los Departamentos de Pichucalco, Mezcalapa, Simojovel, Centro, Chilón, Palenque, Libertad y Comitán, lo que imposibilita su comunicación, progreso y vigilancia que fijada en la residencia de los Poderes en Tuxtla, acaba toda negociación entre San Cristóbal Las Casas y los pueblos de San Felipe Ecatepec, Zinacantán, Chamula, San Andrés, Santiago, Plátanos, San Juan, Magdalenas, Santa Martha, San
Pablo Chalchihuitán, San Pedro Chenalhó, San Miguel Mitontic, Tenejapa, Cancuc, Tenango, San Martín, Sitalá, Guaquitepec, Chilón, Bachajón, Sibacá, Oxchuc, Huistán, Chanal, Amatenango, Aguacatenango, La Reforma, Teopisca, Totolapa, Chiapilla, San Lucas y otros que, relacionados antes estos pueblos con la antigua capital y hoy aislados, no tendrán el consumo de sus esquilmos que les proporcionaba una abundante población en el Centro, enervándose así los brazos del trabajo con prejuicio de la riqueza pública, que estos mismos pueblos sin elementos de vida, acosados por la miseria, sumergidos en la ignorancia y la imposibilidad de pagar tanta contribución, se remontarán unos a las cavernas para volver a su primitivo estado de salvajismo y fomentar una nueva guerra de castas, y otros emigraran a Guatemala como ya está sucediendo; que llevando Ios Poderes a Tuxtla, el Gobierno se priva de los muchos elementos intelectuales y materiales que hay en San Cristóbal Las Casas, porque en esta población es donde residen principalmente los pedagogos, abogados, notarios, ingenieros, jefes militares, sacerdotes, etc., etc. que sacando los Poderes de San Cristóbal Las Casas, donde hay sobrados edificios espaciosos y de mucha comodidad, se llevan a Tuxtla a donde sobre carece de iguales o mejores localidades se están gastando miles en contrato de corte de madera gravosos para rentas del Estado y excesivamente favorables para los agraciados comerciantes; y que no se oculta a ningún ciudadano libre, honrado, imparcial y patriota que el pernicioso decreto del 9 de agosto es a todas luces inconveniente, deberíamos de esperar que el gobernante Sr. Rabasa persuadido por su mal proceder, olvidando rencores y pasioncillas personales, dejara de arruinar Chiapas, porque no sólo es gobernante de Tuxtla, y desearíamos que volviera sobre sus pasos, pero como conocemos su odio e indisposición, especialmente contra veinte mil habitantes de San Cristóbal Las Casas, y sabemos que no retrocede, únicamente esperamos que el ilustre Presidente de la República, Sr. General Porfirio Díaz, impuesto de cuanto pasa en el hoy abatido y desgraciado Estado de Chiapas, ponga un hasta aquía tanto mal, desgracia y ruinas causados por el Gobernante Sr. Emilio Rabasa. 
Víctor Manuel Esponda Jimeno

\section{CAPÍTULO VI}

No terminaremos sin tocar aunque sea someramente, algunos otros puntos de notoria importancia.

Se ha deducido como una de las más poderosas razones para trasladar los Poderes Públicos que Tuxtla es un pueblo de porvenir y que por tal motivo allí debe permanecer el Gobierno, y que San Cristóbal Las Casas, que siempre ha sido capital, es una población muerta que no da esperanzas. Para probar lo contrario, sólo basta traer a la vista de los padrones y de ellos resalta la verdad, sin esfuerzos o guarismos exagerados. Veámoslo:

Tuxtla tenía hace setenta años 6, 000 habitantes hasta hoy cuenta el mismo número.

San Cristóbal Las Casas, tenía es esa época 10, 000 habitantes y hoy asciende la población a 20, 000 ¿Cuál es el pueblo muerto?...

En 1837 el Departamento de Tuxtla tenía 13, 909 habitantes y en 1889 contaba 32, 869.

En los mismos años el Departamento del Centro ha contado respectivamente 18,922 y 66,690 habitantes. ¿Cuál es el pueblo sin porvenir?

Del primero de enero de 1890 al 30 de junio de 1891, fueron recaudadas las siguientes cantidades: por el Centro \$72, 212. 70; Comitán \$55, 342. 59; por Chiapa, \$26, 754. 96; por Chilón, \$16, 083. 39; por la Libertad, \$9, 818. 52; por el Palenque, \$14, 602.61; por Pichucalco, \$39, 701. 31, por Simojovel, \$10, 686.00; por Soconusco \$36, 171.32; por Tonalá \$18, 129. 78; por Tuxtla, $\$ 45,450$. 13; ¿Cuál es el Departamento más rico y el que produce al Erario del Estado y Federal. Por mayor convencimiento, ocúrrase a documentos oficiales, de donde están tomados los anteriores datos, especialmente véanse las Memorias de Gobierno, años 1889 a 1891 que son los más recientes.

Los que anhelan mejorar a Tuxtla a toda costa, aunque sea con perjuicio del Estado, ya no hayan como decir y ponderar que esa ciudad es inminentemente comercial y que por tal motivo los Poderes Públicos allí deben de estar.

No obstante no sabemos si esos optimistas creen que los Poderes Públicos constituyen ya un objeto de mercancía, nos permitimos asegurar que al hacer tal aserción carecen de buenos y sólidos fundamentos. Si
Tuxtla tiene algún movimiento mercantil, es porque la mayor parte de su consumo depende de los pueblos del centro y es evidentemente quitados los elementos de vida de este Departamento, el desconcierto es seguro, y la decantada ciudad comercial, sino queda como está en ese ramo poco adelantará.

Por otra parte, San Cristóbal Las Casas se halla en el Centro, Departamento donde felizmente se goza de todos los climas desde el cálido hasta el frío, y a nadie se le oculta que comunicada esta población con Simojovel por el Norte, con Salto de Agua y Monterías de Jataté por el Oriente, con la progresista y comercial ciudad de Comitán por el s.E. con la de San Bartolomé por el Sur; con el río Grijalva que pasa por Acala, Chiapa de Corzo, Osumasinta, límites de Bombaná, Chicoasén, etc., etc. desde el s.o. hasta el Oeste; ¿No ha de ser esta población con el tiempo otra ciudad de comercio si así se procura?

Mas dado el caso que sólo Tuxtla fuera la única ciudad comercial del Estado, lo que no es así, porque Comitán, Tapachula, Tonalá, Chiapa y Pichucalco lo son, necesario es que digamos aquí que tenemos entendido que la ciencia gubernativa no enseña que los Poderes del Estado han de construirse en las ciudades comerciales, ni menos conocemos ley alguna que así lo prevenga; de otra suerte, la capital de Chiapas en tiempos de paz y no por circunstancias anómalas de repente habríamos de verla en Tapachula, luego en Pichucalco como en Catazajá; la Capital de la República se trasladaría a Chihuahua, Veracruz, San Juan Bautista, etc., etc. y los poderes públicos estarían ambulantes yendo y viniendo de ésta a aquella población en busca del punto que de día en día ofrecería mayor movimiento mercantil, lo que sería absurdo e inadmisible.

Comitán es el Departamento más rico en cuando a sus habitantes han sabido crear y distribuir la riqueza; más si se atiende a la multitud de fincas rústicas y urbanas que hay en el Centro, y a que si no todos, muchos de los Sancristobalenses poseen grandes y hermosas fincas en los demás Departamentos, nadie dejará de comprender cuál es el pueblo más rico del Estado.

Ahora bien si Chiapas gozaba de los beneficios de la Paz y si los demás pueblos marchaban por el sendero 
de su bienestar, debido al acierto, tino y buen gobierno del Presidente de la República, del esclarecido patriota general Porfirio Díaz, si los partidos políticos de otros tiempos se habían extinguido, si San Cristóbal Las Casas y Tuxtla caminaban fraternal y armoniosamente ¿por qué el Gobernador Sr. Lic. Emilio Rabasa vino a renacer odios, a crear divisiones, a recordar rencores y a desfogar todo su enojo, toda su ira y encono contra la capital del Estado? ¿qué delito han cometido los pueblos del Centro que diariamente son el blanco de órdenes terribles, de disposiciones crueles que sólo tienden a la ruina y destrucción?, ¡Sólo el primer Magistrado de la Nación, sólo el héroe del 2 de abril, sólo el supremo mandato de México puede salvar a Chiapas de los peligros que le amenazan, de los abismos en que se hunde, luego que se imponga de la triste y desgraciada situación en que nos hallamos.

Señor presidente de la República: Ios Sancristobalenses y todos los pueblos del Estado esperan vivamente que con vuestro tacto político, con el nunca desmedido patriotismo y desprendimiento con que habéis conquistado vuestros honrosos laureles y vuestras deslumbrantes glorias, dictaréis acertadas disposiciones, y con ojo previsor sabréis evitar para lo futuro y remediar los muchos males que sin razón alguna agobian a la capital San Cristóbal Las Casas y a todo Chiapas. Así nos lo promete vuestro talento gubernativo y así lo reclama la ley, la justicia y la paz nacional.

\section{LOS SANCRISTOBALENSES}

NOTA.- Oportunamente fue remitido el anterior documento a quien corresponde con multitud de firmas que hoy dejan de publicarse por falta de tipos suficientes.

La impresión se hizo en los confines del Estado, por causas de todos conocidas.

Lic. Vicente Pineda.
Notas

${ }^{1}$ Los negocios y arreglos que hizo con Leopoldo Gout y Ciro Farrera son bien conocidos; incluso por sus buenos oficios y relaciones logró que el primero fuera nombrado senador propietario por Chiapas y tal era su compromiso y gratitud con él que al morir Gout propuso ante el Senado que la sesión del 4 de mayo de 1913 se suspendiera por el fallecimiento de dicho senador, "que se guardara duelo y se enlutaran las tribunas". Cuando el general Pimentel, en 1905, había convencido a Díaz de trasladar los poderes a su capital efectiva, Rabasa se opuso y rogó a Díaz que no lo permitiera, pues durante su administración el gobierno de su cargo arrastraba un déficit de $\$ 55,000$, de los cuales $\$ 14,000$ correspondían a la casa Gout. Por otro lado, Ciro Farrera, Emilio Esponda Moguel y otros parientes de Rabasa le suministraban frecuentes préstamos generosos que a la vez favorecían a sus empresas. La sucursal del Banco Nacional en Chiapas la manipuló Rabasa con los terratenientes Moguel, Figueroa, Toledo, Esponda, Farrera, Espinosa, Cueto, entre otros socios capitalistas y directores; su hermano Ramón fue uno de ellos. Pedro del Cueto, español que primeramente se había radicado en Tonalá con otros paisanos suyos, logró hacerse de un cuantioso capital y extendió sus dominios al fértil valle de Jiquipilas-Cintalapa y luego a la novel capital en donde estableció, entre otros negocios, una fábrica de cigarros. Sabedor de que Pimentel pretendía restituir los poderes a su sede original, amenazó que el Banco referido y su compañía no suministrarían dinero a un gobierno negligente.

${ }^{2}$ En esta época, como en las precedentes, San Cristóbal, Comitán, Chiapa y otros municipios comerciaban intensamente con Guatemala; sus relaciones eran cordiales y por ello muchos jóvenes se iban a estudiar al vecino país que, dicho sea de paso, en diferentes momentos dio asilo político a muchos chiapanecos, y esto dio pie para que los capitalistas locales y extranjeros (españoles y alemanes) asentados en la Costa y Depresión Central creyeran que de seguir con esa política se corría el riesgo de que Chiapas se reintegrara a Guatemala y que sus negocios y comercio con México se vieran afectados e interrumpidos. 
${ }^{3}$ Vocabulario de la lengua zendal según el orden de Copanabastla, 1986, Instituto de Investigaciones Filológicas, Centro de Estudios Maya, unAm (Fuentes para el estudio de la cultura maya, 4).

${ }^{4}$ Florinda, Contiene los documentos más importantes referentes á la insurrección de indígenas acaecida en 1869, Felipe Jimeno Jiménez, impresor, 1889, Esquina de la 2. ${ }^{a}$ Calle Avenida Sur, San Cristóbal Las-Casas. [Segunda edición en 2003, preparada por Víctor Manuel Esponda Jimeno, Universidad de Ciencias y Artes de Chiapas, Talleres de Desarrollo Gráfico Editorial, México.]

${ }^{5}$ Para aclarar una confusión respecto al licenciado Pineda, quien nunca contrajo nupcias, con un homónimo que profesó el oficio de sacerdote, es preciso señalar que el último llamado José Vicente Pineda (1829-1894) era originario de Puebla y no tenía parentesco alguno con el mencionado. El presbítero ejercía en la parroquia de Chiapilla; se sabe que enfermó de hidropesía y a causa de ello murió en el Trapiche de La Merced. Este sacerdote tuvo tres hijos, a saber, Antonio, Petrona y Francisco; los varones con Tomasa Juárez y Petrona con Onorata Rosales Estrada.

${ }^{6}$ Opúsculo publicado por la "Imprenta de los Chiapanecos Libres de la Frontera”, a cargo de Celso Costa en 1892. Impreso en los confines del Estado. Se han respetado estilo y ortografía originales del documento.

\section{Bibliografía}

Flores Ruiz, Eduardo, 1985, ElLibro de Oro de San Cristóbal de Las Casas, Gobierno del Estado de Chiapas, p. 103.

Ruiz Abreu, Carlos, 2000, Emilio Rabasa Estevanell: Los combates por la vida (Historia del poder en Chiapas), Gobierno del Estado de Chiapas, Consejo Estatal para la Cultura y las Artes, p. 52, Ed. Ultra, México.

Esponda Jimeno, Víctor Manuel, 2002, Sobre la residencia de los poderes públicos del Estado, Tipografía Flores, San Cristóbal Las Casas, 1913, Reimpreso, Opúsculos 1, Manuel Pineda, Edición privada. Editorial Fray Bartolomé de Las Casas, San Cristóbal de Las Casas, p. 25-68.

De Paz, Eduardo, 2004, La cuestión económica y politica local en Chiapas, 1912; Luis Espinosa, Rastros de sangre. Historia de la revolución en Chiapas, 1912; Víctor Manuel Esponda Jimeno, Opúsculos 2, Timoteo Flores Ruir, edición privada, Editorial Fray Bartolomé de Las Casas, San Cristóbal de Las Casas, Chiapas.

Casahonda Castillo, José, 1963, 50 años de Revolución en Chiapas, Instituto de Ciencias y Artes de Chiapas, Tuxtla Gutiérrez, p. 13. 